\title{
Incidences of poisonings due to Chlorophyllum molybdites in the state of Paraná, Brazil
}

\author{
André August Remi de Meijer ${ }^{*}$, Maria Angela Lopes de Almeida Amazonas ${ }^{2}$, Giselia \\ Burigo Guimarães Rubio ${ }^{3}$ and Rafael Martinez Curial ${ }^{4}$ \\ ${ }^{1}$ Sociedade de Pesquisa em Vida Selvagem e Educação Ambiental; C. P. 305; a_de_meijer@hotmail.com; 80.001- \\ 970; Curitiba - PR - Brasil. ${ }^{2}$ Centro Nacional de Pesquisa de Florestas; Estrada da Ribeira km 111; C.P. 319; \\ angela@cnpf.embrapa.br; 83411-000; Colombo - PR - Brasil. ${ }^{3}$ Secretaria de Estado da Saúde; Centro de Saúde \\ Ambiental; Rua Piquiri 170; giselia@pr.gov.br; 80.230-140; Curitiba - PR - Brasil. ${ }^{4}$ Avenida Marechal Humberto \\ de Alencar Castelo Branco, 1000; Apto. 201; bloco 3; rmcurial@uol.com.br; 82.530-020; Curitiba - PR - Brasil
}

\begin{abstract}
Three recent cases of poisoning by Chlorophyllum molybdites, including the first one known from Brazil, have been reported from the state of Paraná. A morphological description of the material causing the first poisoning was provided and the associated case history has been described in detail. An overview of this species' distribution in Brazil is given.
\end{abstract}

Key words: Chlorophyllum, poisonous fungi, mycetism, Paraná (state) - Brazil

\section{INTRODUCTION}

In the Brazilian state of Paraná, few cases of poisoning by wild mushrooms have been reported (Meijer 2001: 146) but in none of the cases the fungus material was directed to a specialist for the identification, except in the cases described here. On September 16, 2000, a poisoning occurred due to the consumption of a fungus collected from a rural property in the municipality of Araucária, situated in the metropolitan region of Curitiba, state of Paraná. The clinical aspect was partially documented by the Public Health Secretary of Araucária. The site was visited nine days after the poisoning, and a collection of the species was made and identified as Chlorophyllum molybdites (G.Mey.: Fr.) Massee.
The aim of this work was to provide a description about the species and discuss its distribution and toxicity in a general context.

\section{MATERIALS AND METHODS}

The mushroom collections were studied with an Ernst Leitz Wetzlar monocular microscope with $100 \mathrm{X}$ objective, and a $10 \mathrm{X}$ eyepiece with micrometer disc. For the microscopic study of hyaline structures, Congo Red in water was used for the fresh specimens and Congo Red in $10 \%$ ammonium hydroxide for the dried specimens. Amyloidity tests were done with Melzer's reagent prepared according to Singer (1975). Metachromy of spore walls was checked in Cresyl Blue in dilute aqueous solution. Descriptive morphological terms followed Vellinga (1988) and Vellinga and

\footnotetext{
${ }^{*}$ Author for correspondence
} 
Noordeloos (2001). The abbreviation K. and W. refers to Kornerup and Wanscher (1978). Slenderness index $=$ (stipe length $\mathrm{x}$ stipe length) $/$ (stipe thickness $\mathrm{x}$ pileus breadth). $\mathrm{Q}=$ (length of spore) / (breadth of spore). The notation [20/2/1] stands for ' 20 spores measured from 2 basidiocarps belonging to one collection'. HFM refers to 'Herbário Fernando Cardoso', at the Centro Nacional de Pesquisa de Florestas - Embrapa Florestas, Caixa Postal 319, 83411-000 Colombo, Paraná, Brazil. Abbreviations of scientific periodicals and monographs and of authors of taxa follow the Plant Names Project (http://www.ipni.org).

\section{RESULTS}

\section{Morphological description}

Short characteristic: Medium-sized to large basidiocarps. Pileus, when opened, with smooth brown disc and with brown scales on white background colour. Lamellae remote from stipe, white at first and mostly gaining green or olive tint on maturing. Stipe with smooth to striate surface, and with clavate base and thick, membranous, double-edged annulus. White context changing to greyish orange on bruising. Fresh spore print greyish green. Spores mostly $10-13$ x $8 \mu \mathrm{m}$, ovoid to amygdaliform, dextrinoid, thick-walled, with broad, truncate germ pore.

Macroscopical characters: Basidiocarps gregarious, densely gregarious or fasciculate. Pileus when young and unopened 10-60 mm diam. and 9-45 $\mathrm{mm}$ high, globose to hemispherical, evenly brown (K. and W. 6E4); when opened 60$230 \mathrm{~mm}$ diam., from hemispherical with inflexed margin to plano-convex with broad, low umbo, surface layer remaining continuous on the disc, but around it disrupting into dispersed, large (about 5 $\mathrm{mm}$ diam.), appressed scales with uplifted edge; the background remaining rather smooth or becoming densely squarrose or appressed squamulose from small (about $1.5 \mathrm{~mm}$ diam.) and triangular, whitish then brownish orange $(5 \mathrm{C} 3)$ scales; the background between scales remaining white; dry all over, non-hygrophanous, entire outer margin $(10 \mathrm{~mm}$ width) sulcate-striate, or smooth; thin- to thick-fleshed (context $<24$ mm thick near centre and $<15 \mathrm{~mm}$ thick above midpoint of lamellae). Lamellae free, $<3 \mathrm{~mm}$ remote from stipe, close, $<10 \mathrm{~mm}$ broad in unopened pileus and $<24 \mathrm{~mm}$ broad in opened pileus, first pure white, then yellowish white/greenish grey (1AB2) or pale green/greyish green (27AB3), finally olive brown (4EF3), with concolorous, even edge; lamellulae attenuate. Stipe when young with pileus still unopened $18-110 \mathrm{~mm}$ long, $12-21 \mathrm{~mm}$ wide at base and 5-11 mm wide at narrowest part; when mature and pileus opened 100-187 mm long, 15$29 \mathrm{~mm}$ wide at base and $9-15 \mathrm{~mm}$ wide at narrowest part; base clavate, above base gradually slightly attenuated to apex; at first stuffed, becoming fistulose; annulate; at first entirely pure white, below annulus finally becoming partially or entirely yellowish brown (5DE4), turning greyish brown $(8 \mathrm{~F} 3)$ on drying, above annulus remaining white; surface smooth, below annulus longitudinally striate when fully dry, macroscopically subglabrous; basal mycelium cottony and pure white. Slenderness index $=7-24$. Annulus superior, descending, thick membranous, persistent, immovable when fresh, $<8 \mathrm{~mm}$ broad, white and smooth above, edge double, inferior edge concolorous with the pileus centre. Context pure white; after bruising slightly or strongly and quickly changing to greyish orange (6B3) in all parts of stipe and pileus centre, finally brown (6E4); odour weak; taste mild. Spore print greyish green (27-29C4) when fresh.

Microscopical characters: Basidiospores [20/2/1] 10-13 x (7.2-)7.8-8(-8.8) $\mu \mathrm{m}$ (measured from spore prints), $\mathrm{Q}=1.3-1.6(-1.8)$, average $\mathrm{Q}=1.4$, ovoid to amygdaliform, hyaline, containing one large guttule, dextrinoid; apex not papillate, germ pore truncate and $<2 \mu \mathrm{m}$ broad; wall smooth, $<1$ $\mu \mathrm{m}$ thick; hilar appendage 1.5 x $1 \mu \mathrm{m}$. Basidia 25$29 \times 12-13 \mu \mathrm{m}, 4$-spored, clavate. Cheilocystidia densely packed, 32-45 x 14-38 $\mu \mathrm{m}$, pyriform, clavate or spheropedunculate, smooth, thin-walled, hyaline or more frequently with evenly dissolved, very pale yellowish grey intracellular pigment. Pleurocystidia absent. Hymenophoral trama made up of parallel chains of 4-15 $\mu \mathrm{m}$ broad, thinwalled, smooth, non-amyloid hyphae, the narrower ones strictly cylindrical, the broader ones constricted at the septa. Pileus covering in centre made up of cylindrical-strangulated, smooth, thinwalled to very slightly thick-walled, obtuse hyphae 20-100 x 6-12 $\mu \mathrm{m}$, with pale brown intracellular pigment. Clamp-connections easily found in the pileus covering.

- Material studied: BRAZIL, state of Paraná, Araucária, Palmital district, $25^{\circ} 38^{\prime} \mathrm{S}, 4^{\circ} 23^{\prime} \mathrm{W}$; 25.ix.2000, leg. R.M. Curial (de Meijer 3786; HFC 
274); same locality, 18.x.2000, leg. A.A.R. de Meijer and M.A.L. de A. Amazonas (de Meijer 3792; HFC 279).

- Habitat: at farm, on heap of bare, disturbed, peaty soil mixed with sawdust and enriched by pig excrement.

The poisoning case in the municipality of Araucária was well documented. The victims (with names on file in the authors' records), a farm labourer (at that time aged 43), his wife (a housewife, aged 37) and two sons (aged 21 and 23) - collected two large and four small fruitbodies of the species on a single spot. The mushrooms were prepared for the afternoon snack by soaking and cooking in oil for (at most) 10 to 15 minutes, with the addition of salt and garlic based seasonings. The mushrooms were consumed at 3 p.m., together with roasted chicken heart (which had been prepared separately), black coffee, CocaCola and bread. One of the victims did not drink coffee, another did not drink Coca-Cola and yet another did not eat bread. About two hours after the mushroom consumption all four victims experienced a bad taste reminiscent of the mushroom flavour rising back in the throat. This quickly turned to real nausea and, then, all four started to vomit with great intensity. In all male victims the vomit was bloody. One of the sons with whom the symptoms started a few minutes later - still managed to telephone to his brother in Curitiba, asking him to come along quickly by car. But, as he did not tell him what was happening not wanting to cause unduly alarm possibly resulting in high speed and a traffic accident - the brother arrived only one hour and a half later.

During this phase of vomiting all four suffered from colicky abdominal pain, which the woman described as being comparable in intensity as when giving birth to a child. At a moment, the woman fainted for a short while. In all four victims, the vomiting was so powerful, that - a few minutes after the process had started - they felt weakness to the point of being almost unable to move their legs, and they could no longer stand upright. It was not known if this was an effect of the dehydration and electrolyte imbalance caused by profuse vomiting or some direct toxicity effect. None of the victims felt able to walk to a neighbour to ask him to drive them to a hospital. Thus, they had no option except to wait for the unharmed son's arrival. The father felt he could be dying, and was already starting to accept this fate, as he knew he would make the transition in the best company ever. When his son finally arrived, a quick car-drive brought them to the nearest health care centre. During this 5 minutes trip the woman fainted four times. When arriving at the health care centre, nearly four hours after ingestion of the mushrooms, all four were still vomiting. Administration of intravenous fluid consisting of $5 \%$ glucose to rehydrate the victims immediately started the treatment. In addition, they received intramuscular injections with two medicaments, viz. Buscopan (N-butilescopolamine bromide and sodium dipirone), for relieving abdominal pain, and Plasil (metoclopramide chlorhydrate) to control vomiting. During this treatment all victims, except the father, felt a high pulse-rate. When leaving the centre, on their way to the car, the father and his oldest son had a fainting sensation and quickly returned to the centre to lay down for a while. In the meantime, the youngest son started to get diarrhoea. This also happened in the evening to the other two men, and to the woman in the next day. The stools were watery, but with the woman not the men - it was pale blood-stained. Vomiting stopped soon after having left the centre and all four continued to take an oral rehydratant during the following 24 hours. The day after the poisoning all victims except the father felt intense headaches and all four experienced intermittent cold sweating. In several more days all victims felt a kind of bad taste and a slight disgust of food in general. It took them a full week to feel completely recovered from the poisoning. Amongst the victims, the woman seems to have suffered the most. She explained this by her weak and stressed condition at the moment the poisoning happened, because she had given much assistance to her ailing mother, who had died only one month before.

All four victims told us, afterwards, to regard the attendance at the health-care centre excellent. Actually, the treatment hardly differs from that given to a victim of the same fungus in India (Natarajan and Kaviyarasan 1991). But according to Lehmann and Khazan (1992) in the treatment of C. molybdites poisoning no materials that reduce the rate of gut motility should be administered.

The symptoms mentioned in this case history, particularly the intensive vomiting, and the moment of their appearance - rather soon after the ingestion - are typical for gastrointestinal syndrome and this is indeed the group of mushroom poisonings in which $C$. molybdites has always been classified. 
After this first proven poisoning with $C$. molybdites two more cases followed in the state of Paraná involving the same species, one in 2000 and one in 2003. In both cases the fungus material was directed to AARM for identification, through the Secretaria de Estado da Saúde in Curitiba. These cases were the following:

- 16 October 2000, in the municipality of Marumbi $\left(23^{\circ} 46^{\prime} \mathrm{S}, 51^{\circ} 44^{\prime} \mathrm{W}\right)$, a farm labourer aged 44 ate (raw or cooked?) one tenth of a mushroom pileus and started to feel the symptoms one and a half hour after consumption. More data on this case were not made available to us. This material has been preserved as exsiccates HFC 277 and de Meijer 4166. The spore size in this collection is $10-12$ x 7.8-8 $\mu \mathrm{m}(\mathrm{Q}=1.25-1.5)$;

- on 17 February 2003, in the municipality of Irati, Monjolo district $\left(25^{\circ} 33^{\prime} \mathrm{S}, 50^{\circ} 42^{\prime} \mathrm{W}\right)$, a housewife aged 26 collected this fungus in a pasture near her home, ate a little fragment raw and cooked the rest at home for dinner, which then was consumed by herself, a man aged 22, a girl aged 12 and a boy aged 10. All four persons started to feel the first symptoms of poisoning three hours after ingestion. All four then experienced lethargy for a period of 5-13 hours, and nausea, vomiting and excessive salivation for a period of 2-5 hours. All but one (the man) got colic (lasting 3-7 hours), all but one (the girl) got diarrhoea (lasting 3-7 hours) and one (the woman) felt dizzy (for 4 hours). All four got hospitalised in the evening (there they received a symptomatic treatment: endovenose re-hydration, Plasil and Buscopan) and were discharged from the hospital 20 hours afterwards. The fungus material causing this poisoning has been preserved as exsiccate de Meijer 4148. In this collection spore size is 9-12(-14) x 7-8(-9) $\mu \mathrm{m}(\mathrm{Q}=1.3-1.5[-$ $1.6])$.

The basidiospore size of the three $C$. molybdites collections causing poisoning in Paraná thus varies between 9-13(-14) x 7-9 $\mu \mathrm{m}$.

The first author has been studying macromycetes in Paraná since 1979 (Meijer 2001), and encountered $C$. molybdites only three times, so the species is apparently rare on the Curitiba tableland where he has concentrated his work. Three more collections, made in Paraná by others, have come to his hands over the years. These collections, except those causing the poisonings and already listed above, are the following (preserved as exsiccata, unless otherwise indicated):

1989, April 19, Curitiba, Prado Velho quarter, campus of the Pontificia Universidiade Católica
(252 $\left.27^{\prime} \mathrm{S}, 4^{\circ} 15^{\prime} \mathrm{W}\right)$, leg. M. de L. Todeschini (de Meijer 1867);

1993, February 17, Pontal do Paraná, Pontal do

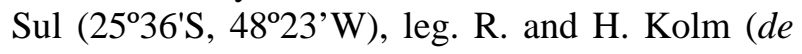
Meijer 2505);

1993, March 25, São José dos Pinhais, Harry Feeken Street $\left(25^{\circ} 33^{\prime} S, 49^{\circ} 11^{\prime} \mathrm{W}\right)$, leg. A.A.R. de Meijer (de Meijer 2602);

2000, December 14, São José dos Pinhais, Roça Velha district $\left(25^{\circ} 42^{\prime} \mathrm{S}, 49^{\circ} 05^{\prime} \mathrm{W}\right)$, leg. A.A.R. de Meijer (mat. not preserved);

2003, October 13, Antonina, Lageado (2519'S, $39^{\circ} 35^{\prime} \mathrm{W}$ ), leg. A.A.R. de Meijer (mat. not preserved);

2005, May, Pontal do Paraná, Pontal do Sul, Rua dos Flamboyants $\left(25^{\circ} 36^{\prime} \mathrm{S}, 4^{\circ} 23^{\prime} \mathrm{W}\right)$, leg. H. Kolm (de Meijer 4336).

Menolli Jr. found the species in Londrina $\left(23^{\circ} 23^{\prime} \mathrm{S}\right.$, $51^{\circ} 11^{\prime} \mathrm{W}$ ), northern Paraná, in 2003 (Menolli Jr. and Ishikawa 2004).

The habitat and distribution of C. molybdites in Paraná is as follows. Rare in the temperatesubtropical climate zone, not rare in the subtropical-tropical zone; in the open landscape, in lawns among grass, and on disturbed soil, also on heaps of sawdust and/or soil mixed with excrement of domestic animals (poultry, pigs); from sea level to $1000 \mathrm{~m}$. Fruiting from September to end of May.

\section{DISCUSSION}

Chlorophyllum molybdites has been a frequent cause of mycetism in all continents except Europe, as has been reported by many authors, viz. Avizohar-Hershenzon (1967), Natarajan and Kaviyarasan (1991) and Graff $(1913,1927)$ for Asia; Grgurinovic (1997), Southcott (1974) and Young (1989) for Australia; Arora (1991), CFSAN (2003), Eilers and Nelson (1974), Lehmann and Khazan (1992), Levitan et al. (1981), Pérez-Silva and Herrera (1986) and many others for North America; and Floch et al. (1966) and Singer (1969, 1975) for South America. Walleyn and Rammeloo (1994) summarise all references for Africa, and Reid and Eicker (1991) provide references for most continents. Chorophyllum.molybdites in North America is the species that causes more poisonings than any other mushroom, particularly because of its resemblance with $C$. rachodes (Vittad.) Vellinga and its ample occurrence in 
lawns in urban areas (Arora 1991, Lehmann and Khazan 1992). Most cases of mycetism in residents of tropical metropoles are caused by this species (Courtecuisse and Duhem 1994). Its distribution is indeed mainly tropical-subtropical. In Europe it occasionally appears in hothouses and other artificially heated environments (Dennis 1952: 463, Vellinga 1990, Watling 1991). In America its northernmost occurrence indoors is in south-eastern Canada (Reid and Eicker 1991) and the southernmost occurrence is in the Argentinean province of Buenos Aires (Reid and Eicker 1991, Singer and Digilio 1952). Like many other species with an intercontinental distribution, it has been described under many names and extensive lists of synonyms were supplied by Grgurinovic (1997), Pegler (1977, 1983), Reid and Eicker (1991), Singer (1975), and others. Altogether there are no less then eight or nine epithets for this species, viz. camporum, congolensis, esculentum, glaziovii, guadelupensis, molybdites, morganii, ochrospora, and probably also chlorospora. It should be noted that C. globosum (Mossebo) Vellinga, from western Africa (Mossebo et al. 2000), is indeed a different species (Vellinga and de Kok 2002, Vellinga et al. 2003), though there might be an older name for it.

In South America the species has been reported, south to north - listing all countries - from Argentina (including type of Annularia camporum Speg.), Brazil, Venezuela, Guiana (Dennis 1952, Pegler 1983; types of Chlorophyllum esculentum Massee and Lepiota ochrospora Cooke and Massee), French Guyana (Courtecuisse et al. 1996) and Trinidad (Reid and Eicker 1991 and references therein). We have not seen any published records of Chile, Bolivia, Ecuador and Colombia. In Brazil it is known from the states of Rio Grande do Sul (municipalities of Santa Cruz do Sul and São Leopoldo; Pereira 2001, Rick 1961, Singer 1953b), Paraná (data presented here), São Paulo (São Paulo and Serra de Cantareira; Pegler 1997), Rio de Janeiro (Dennis 1952, Pegler 1983, Singer 1955; all these authors referring to the holotype of Agaricus glaziovii Berk.) and Pernambuco (Recife; Reid and Eicker 1991).

The data given in Table 1 show that in $C$. molybdites the basidiocarps have slenderness index $<25$, and the spore quotient $(\mathrm{Q})$ normally varies between 1.2 and 1.6 (the measurements of
Soto et al. [2000] are likely to include immature and abnormal spores). The basidiocarps thus generally vary between rather stout and relatively slender and the spores between broadly ellipsoid and ellipsoid. A basidiocarp collected by Alfred Möller in Blumenau, in the State of Santa Catarina, and described by Bresadola (1896) as Lepiota molybdites is too slim (slenderness index $=47)$ for $C$. molybdites, the stipe quite long ( 25 $\mathrm{cm})$ and the spores too long $(15-17 \times 9 \mu \mathrm{m})$ and too oblong $(\mathrm{Q}=1.7-1.9)$.

In the state of Paraná, in the same type of open habitats where $C$. molybdites usually occurs, two much more common and edible species occur, Macrolepiota bonaerensis (Speg.) Singer and Chlorophyllum hortense (Murrill) Vellinga, that might well be confused with it, but differ in the white spore print. In addition, $M$. bonaerensis shows no reddening of the flesh, as occurs in both of the other species. And in $C$. hortense the inferior edge of the annulus is white and not thickened, whilst it is thickened and brown in both of the others. Microscopically, the species are very easily distinguished: $M$. bonaerensis differs from C. molybdites in having much larger spores (13-21 x $8.5-13 \mu \mathrm{m}$ in the Paraná material), whilst $C$. hortense differs from it in having slightly smaller (in Paraná: 8.5-11 x 6-8 $\mu \mathrm{m}$ ) non-truncate spores without a germ pore, 2-spored basidia and usually narrower cheilocystidia $(5-10 \mu \mathrm{m}$ broad in Paraná). Macrolepiota bonaerensis is edible (Singer 1953a, Singer and Digilio 1951), and so is C. hortense (Boa 2004).

The genus Chlorophyllum was considered to differ from Macrolepiota in the green spore colour and in the absence of clamp-connections (cf. Singer 1948, 1951). Later however, clamp-connections were found to be present in the type species of Chlorophyllum (Heinemann 1968, Natarajan and Manjula 1981, Singer 1969, Sundberg 1971), whilst in some Macrolepiota species they are rare of absent (Vellinga et al. 2003). The only difference which then remained between the two genera was the colour of the spore print (green in Chlorophyllum and white in Macrolepiota), but some authors did not consider this character alone sufficient for maintaining the generic separation and so the former was synonymized with the latter (Moreno et al. 1995). 
Table 1 - Overview of some morphological characters of Chlorophyllum molybdites, based on collections made in the state of Paraná and on data from literature.

\begin{tabular}{|c|c|c|c|c|}
\hline Source & Locality & $\begin{array}{l}\text { Material described } \\
\text { as having caused a } \\
\text { poisoning }\end{array}$ & Spore size $(\mu \mathrm{m})$ & $\begin{array}{l}Q \text { (estimated } \\
\text { by the } \\
\text { present } \\
\text { authors) }\end{array}$ \\
\hline Avizohar-Hershenzon (1967) & Israel & unspecified & $(7.5-) 8.25-10.5 \times(5.25-) 6.75-7.5$ & $1.2-1.4$ \\
\hline Grgurinovic (1997: 439) & Australia & Yes! & $9.6-12.8(-13.9) \times 7.2-9.0$ & given as 1.4 \\
\hline Moreno et al. (1995) & Canary Islands & no & $9.5-12.0 \times 6.0-8.0$ & $1.5-1.6$ \\
\hline Natarajan \& Manjula (1981) & Southern India & no & $9.9-11.0 \times 6.6-7.7$ & $1.4-1.5$ \\
\hline $\begin{array}{l}\text { Pegler }(1977,1983 \text {; both } \\
\text { descriptions are identical) }\end{array}$ & $\begin{array}{l}\text { Africa and the } \\
\text { Americas }\end{array}$ & unspecified & $8-11 \times 6.2-8$ & given as 1.34 \\
\hline Pérez-Silva \& Herrera (1986) & Mexico & unspecified & $10.0-10.9 \times 6.8-8.5$ & $1.3-1.5$ \\
\hline $\begin{array}{l}\text { Reid \& Eicker (1991: 318- } \\
\text { 320) }\end{array}$ & South Africa & unspecified & $8.0-10.0 \times 6.5-7.2$ & $1.3-1.4$ \\
\hline Singer (1948: 138) & Florida (U.S.A.) & no & $10.2-13.0 \times 6.8-8.8$ & 1.5 \\
\hline Singer (1969: 160) & Congo (Africa) & $\begin{array}{l}\text { Eaten by the } \\
\text { collector. } \\
\text { Apparently non- } \\
\text { poisonous. }\end{array}$ & $8.7-11.0(-12.5) \times 5.8-7.2$ & $1.5(-1.74)$ \\
\hline Singer (1969: 160) & Argentina & Yes! & $\begin{array}{l}(9.0-) 9.5-10.5(-12.0) \times 7.0-7.5 \text {; from spore print } \\
9.0-10.5(-12.0) \times 6.8-7.8\end{array}$ & 1.5 \\
\hline Soto et al. (2000) & Argentina & yes, probably & $7-16 \times 6-9$ & $1.2-1.8$ \\
\hline Sundberg (1968) & California (U.S.A.) & unspecified & $(7.7-) 10.3-12.2(-13.5) \times(6.3-) 7.7-9.0(-10.9)$ & $(1.2-) 1.35$ \\
\hline Watling (1991) & Scotland & no & $8-11 \times 6-8$ & 1.35 \\
\hline The present paper & Paraná (Brazil) & Yes! & $\begin{array}{l}(9-) 10-13(-14) \times 7.0-8.0(-9.0) \text {; from spore print } \\
\text { s } 10-13 \times(7.2-) 7.8-8.0(-8.8)\end{array}$ & $1.3-1.6(-1.8)$ \\
\hline $\begin{array}{l}\text { ALL SOURCES LISTED } \\
\text { (except Soto et al. 2000, who } \\
\text { apparently included abnormal } \\
\text { spores) }\end{array}$ & All continents & & $7.5-14.0 \times 5.8-9.0$ & $1.2-1.6(-1.8)$ \\
\hline \multicolumn{2}{|l|}{ Cheilocystidium size $(\mu \mathrm{m})$} & $\begin{array}{l}\text { Pileus diameter } \\
(\mathrm{cm})\end{array}$ & Stipe size $(\mathbf{c m})$ & $\begin{array}{l}\text { Slen- } \\
\text { der- } \\
\text { ness Index }\end{array}$ \\
\hline \multicolumn{2}{|l|}{$27-36 \times 15-19.5$} & $8-16(-20)$ & $10-20 \times 1.5-2.0$ (thickness base $2.5-4.0$ ) & $8-13$ \\
\hline \multicolumn{2}{|l|}{$22.0-41.6 \times 12.0-20.4$} & $<24$ & $<28 x<2.5$ & 13 \\
\hline \multicolumn{2}{|l|}{$25-35 \times 10-15$} & $7-20$ & $5-25 \times 1-2($ thickness base $<4.0)$ & $3.6-25$ \\
\hline \multicolumn{2}{|l|}{$24.2-33.0 \times 18.7-22.0$} & $7-10$ & $11-14 \times 1.3-1.5$ & $12-13$ \\
\hline \multicolumn{2}{|l|}{$27-45 \times 10-20$} & $5-24$ & $11-28 \times 1.3-2.5$ & $1.3-19$ \\
\hline \multicolumn{2}{|l|}{$29-35 \times 10-18(-20)$} & $4-15$ & $6-15(-18) \times 1.5-2.0$ (thickness base $2.5-3.0(-5.0)$ & $6-8(-11)$ \\
\hline \multicolumn{2}{|l|}{$25-50 \times 17-21$} & $<12(-30)$ & $<12(-25) \times<2.0(-2.5)$ & $6(-8)$ \\
\hline \multicolumn{2}{|l|}{$40-60 \times 10-16.5$} & $4.7-19$ & $7-20 \times 1.0-1.4$ (thickness base $1.1-3.5)$ & $10-15$ \\
\hline \multicolumn{2}{|l|}{ size not given } & size not given & size not given & - \\
\hline \multicolumn{2}{|l|}{$20-34(-50) \times 6.5-) 11-20$} & size not given & size not given & - \\
\hline \multicolumn{2}{|l|}{$35-45 \times 9-15$} & $6-14$ & $5-14 \times 0.7-1.3$ & $6-11$ \\
\hline \multicolumn{2}{|c|}{$(18.0-) 21.9-47.4(-62.4) \times(9.5-) 10.3-25.5$} & $4.5-15.5$ & $5.7-12 \times 0.6-1.5$ (apex) & $6-12$ \\
\hline \multicolumn{2}{|l|}{ size not given } & $(6-) 13-20$ & $12-16 \times 1.1-1.4$ (thickness base $1.5-2.7$ ) & $9-10(-22)$ \\
\hline \multicolumn{2}{|l|}{$33-45 \times 14-38$} & $1-23$ & $1.8-18.7 \times 0.5-1.5$ (thickness base $<2.9)$ & $7-24$ \\
\hline \multicolumn{2}{|l|}{$18.0-62.4 \times(6.5-) 9.0-38.0$} & $1-24(-30)$ & $1.8-28.0 \times 0.5-2.0($ thickness base $<3.5)$ & $1.3-25.0$ \\
\hline
\end{tabular}

Recently, results of molecular studies have shown that the genera can best be maintained separate (Johnson 1999, Johnson and Vilgalys 1998). Weresub (1971) mentioned a difference in spore wall reactions between $C$. molybdites and Lepiota brunnea, but this works only for mature spores; in young spores the same reactions are visible (obscured in mature spores of $C$. molybdites by the colour of the spore wall) (Vellinga 2003a: 26). As a consequence Vellinga (2002, 2003b) incorporated many white-spored species in Chlorophyllum, including three of the species cited above: C. hortense, $C$. rachodes and L. brunnea (C. brunneem (Farl. and Burt) Vellinga). In Paraná
C. rachodes and $C$. brunneum have never been found.

It has always been stated that, whilst Chlorophyllum molybdites is usually considered poisonous, some collections are eaten without causing any problems, at least not to certain individuals (cf. Murrill 1910, Graff 1927). Many speculations have been made about the possible reasons. A few authors have suggested that there may be two (or more) morphologically distinguishable taxa (Heinemann 1968, Singer 1955), but such characters that would separate them remain insufficiently elaborated (Dennis 1970, Heim 1978, Singer 1975, 1979). Singer 
(1975) considers unlikely the possibility that amongst green-spored Chlorophyllums one would be poisonous and another one edible. Pegler (1977, 1983) distinguishes only one green-spored species and suggests that the toxicity of the fungus could be dependent upon climatic and habitat factors alone or, and this is more widely accepted, upon the susceptibility of the individual (Benjamin 1995, Graff 1927, Reid and Eicker 1991). Floch et al. (1966) have shown that poisonous material from French Guiana contained a toxic, watersoluble substance which was extremely labile with respect to time and temperature. Eilers and Nelson (1974) demonstrated that (one of) the toxin(s) is indeed a thermo-unstable protein molecule that is destroyed when the mushroom is cooked at $70{ }^{\circ} \mathrm{C}$ during thirty minutes. So, this particular toxin can apparently be made harmless by cooking the mushroom thoroughly and lastingly (Young 1989). Some studies have suggested that the poison presents cholinergic type effects (Floch et al. 1966), but Eilers and Nelson (1974) concluded that the toxin is probably not a choline derivative (cf. Lehmann and Khazan 1992). The species may as well be poisonous to mice and chicks if administered in high concentration (Eilers and Nelson 1974), and to dogs (Soto et al. 2000).

Edible material belonging to a green-spored Chlorophyllum has been reported from French Guiana (Pegler 1977, 1983) and some other American and African countries (Rammeloo and Walleyn 1993, Reid and Eicker 1991, Singer 1969), but in Asia green-spored Chlorophyllum is apparently consistently considered poisonous (Avizohar-Hershenzon 1967, Chang and Xiaolan 1995, Graff 1927, Imazeki et al. 1988).

In this connection it may be important to add the following information. The senior victim of the poisoning case in Araucária, Paraná, had acquired the habit of eating wild mushrooms from his father, who, on his turn, had learned it from his father, an immigrant from Italy. In the 1930s this grandfather used to collect wild mushrooms to sell at local markets nearby the city of Curitiba. Nowadays, no commercial collection of wild mushrooms exists in this area. Since the death of his father, twelve years before the poisoning case, he had collected and consumed edible mushrooms only at one occasion. Curiously enough, he insists that he consumed the same mushroom then, but did not experience ill effects. As he made this collection at a different site it cannot be excluded that that was in fact the edible Macrolepiota bonaerensis. The other possibility is that he indeed ate $C$. molybdites, but had either cooked it more thoroughly or that he ate fruitbodies in a more advanced stage of development. A hypothesis exists that this toxic species can sometimes become less toxic, even edible at maturity, when the lamellae have turned green (Reid and Eicker 1991). But this remains to be clarified and no risks should be taken with this species.

Though the symptoms of $C$. molybdites poisoning are serious, consumption of this fungus has only once or twice been fatal, in both cases to toddlers (Benjamin 1995, Lehmann and Khazan 1992, Reid and Eicker 1991). Since this mushroom species occurs frequently in irrigated lawns it is likely to be found there by children, who consider this very attractive looking mushroom 'irresistible' (Arora 1986, 1991). Consequently, it is very important that the Brazilians get warned against it. For this reason in Paraná much publicity has been given to the first poisoning case and it was communicated to the general public through television (TV Globo) and press (Estado do Paraná newspaper) on October 18 and 19, 2000, when a general warning against the consumption of any wild mushrooms without accurate identification was also given. A communication to the scientific community was also made during the third Brazilian Congress of Mycology (Amazonas et al. 2001). It is fortunate that Guerrero and Homrich (1999) have included this species in their popular field guide, with a coloured picture of it on the front cover.

The three recent cases in Paraná are apparently the first $C$. molybdites poisonings reported for Brazil. Because of the importance of this mushroom as a potential Brazilian health risk we would like to give it a common name in Portuguese. We propose: guarda-sol-de esporos-verdes, which is a literal translation of green-spored parasol, as it is aptly called in North-America (Arora 1986, 1991).

\section{ACKNOWLEDGEMENTS}

The authors are very grateful to the victims from the poisoning in Araucária for their kind collaboration and willingness to supply us with all necessary details. Much appreciated is the spontaneous help of Tjakko Stijve with the linguistics of an early version of this paper and in sending us many literature items. Else Vellinga and an anonymous reviewer are gratefully 
acknowledged for their critical read of the last versions and for their valuable suggestions and John Lennie is thanked for his help with the linguistics. We thank the late Dr. Dante Romanó for the valuable suggestion made in his letter of 14 November 2000 to the first author.

\section{RESUMO}

Três casos recentes de envenenamento por Chlorophyllum molybdites, incluindo o primeiro caso conhecido para o Brasil, são relatados do Estado do Paraná. Uma descrição morfológica do material que causou o primeiro envenenamento é apresentada, assim como uma narrativa detalhada do respectivo caso clínico. É, ainda, fornecido um panorama da distribuição desta espécie no Brasil.

\section{REFERENCES}

Amazonas, M. A. L. de A., A. A. R. de Meijer, R. M. Curial and G. B. G. Rubio (2001), Envenenamento por Chlorophyllum molybdites no Paraná. In: Congresso Brasileiro de Micologia, 3., 2001, Águas de Lindóia. Anais. São Paulo: Sociedade Brasileiro de Micologia, 2001. p. 49

Arora, D. (1986), Mushrooms demistified. A comprehensive guide to the fleshy fungi, Ed. 2. Ten Speed Press, Berkeley. 959 pp.

Arora, D. (1991), All that the rain promises and more ... A hip pocket guide to western mushrooms. Ten Speed Press, Berkeley. 265 pp.

Avizohar-Hershenzon, Z. (1967), Chlorophyllum molybdites (Meyer ex Fr.) Mass. in Israel. Israel J. Bot. 16, 63-69

Benjamin, D. R. (1995), Mushrooms, poisons and panaceas: a handbook for naturalists, mycologists and physicians. W. H. Freemann and Co., New York. $422 \mathrm{pp}$.

Bessey, E. A. (1939), A case of poisoning by Lepiota morgani. Mycologia 31, 109-110

Boa, E. (2004),.Wild edible fungi - A global overview of their use and importance to people. (In: FAO Technical Papers - Non-wood Forest Products, 17). Food and Agriculture Organization of the United Nations, Rome. 147 pp.

Bresadola, G. (1896), Fungi Brasilienses lecti a cl. Dr. Alfredo Möller. Hedwigia 35, 276-302.

CFSAN (= Center for Food Safety and Applied Nutrition, U.S. Food and Drug Administration). (2003), Foodborne pathogenic microorganisms and natural toxins handbook. - [Online Database; last updated on Jan. 30, 2003]. Available through: http://www.cfsan.fda.gov/ mow/.
Chang, S-T. and M. Xiaolan (1995), Hong Kong mushrooms. The Chinese University Press, Hong Kong. $1 x v+470$ pp.

Courtecuisse, R. and B. Duhem. (1994), Guide des champignons de France et d'Europe. Delachaux et Niestlé, Lausanne. 480 pp.

Courtecuisse, R., G. J. Samuels, M. Hoff, A. Y. Rossman, G. Cremers, S. M. Huhndorf and S. L. Stephenson (1996), Check-list of fungi from French Guiana. Mycotaxon 57, 1-85

Dennis, R. W. G. (1952), Lepiota and allied genera in Trinidad, British West Indies. Kew Bull. '1952', 459499.

Dennis, R. W. G. (1970), Fungus Flora of Venezuela and adjacent countries. Kew Bull. Addit. Ser. 3, 1-531

Eilers, F. I. and L. R. Nelson (1974), Characterization and partial purification of the toxin of Lepiota morganii. Toxicon 12, 557-563

Floch, H., C. Labarbe and J. Roffi (1966), Étude expérimentale de la toxicité de la Lépiote de Morgan. Rev. Mycol. (Paris) 31, 317-322.

Graff, P. W. (1913), Additions to the basidiomycetous flora of the Philippines. Philipp. J. Sci. 8, 299-310

Graff, P. W. (1927), The green-spored Lepiota. Mycologia 19, 322-326.

Grgurinovic, C. A. (1997), Larger Fungi of South Australia. The Botanic Gardens of Adelaide and State Herbarium and The Flora and Fauna of South Australia Handbooks Committee, Adelaide. 725 pp.

Guerrero, R. T. and M. H. Homrich (1999), Fungos macroscópicos comuns no Rio Grande do Sul, Ed. 2. Editora da Universidade Federal do Rio Grande do Sul, Porto Alegre. 124 pp.

Heim, R. (1978), Les champignons toxiques et hallucinogènes, Ed. 2. Edit. Boubée, Paris. 270 pp.

Heinemann, P. (1968), Le genre Chlorophyllum Mass. (Leucocoprineae). Aperçu systématique et description des espèces congolaises. Bull. Jard. Bot. Belg. 38, 195-206.

Imazeki, R., Y. Otani and T. Hongo (1988), Fungi of Japan. Yama-Kei Publishers, Tokyo. 624 pp.

Johnson, J. (1999), Phylogenetic relationships within Lepiota sensu lato based on morphological and molecular data. Mycologia 91, 443-458.

Johnson, J. and R. Vilgalys. (1998. Phylogenetic systematics of Lepiota sensu lato based on nuclear large subunit rDNA evidence. Mycologia 90: 971-979

Kornerup, A. and J. H. Wanscher (1978), Methuen handbook of colour, Ed. 3. Eyre Methuen, London. $252 \mathrm{pp}$.

Lehmann, P. F. and U. Khazan (1992), Mushroom poisoning by Chlorophyllum molybdites in the Midwest United States. Cases and a review of the syndrome. Mycopathol. 118, 3-13. 
Levitan, D., J. I. Macy and J. Weissman (1981), Mechanism of gastrointestinal hemorrhage in a case of mushroom poisoning by Chlorophyllum molybdites. Toxicon 19, 179-180.

Meijer, A. A. R. de (2001), Mycological work in the Brazilian state of Paraná. Nova Hedwigia 72, 105-159

Menolli Jr., N. and N. K. Ishikawa (2004), Identificação de cogumelo tóxico, Chlorophyllum molybdites, encontrado no campus da Universidade Estadual de Londrina. In: I Simpósio Integrado dos Bacharelados em Biomedicina e I Mostra de Painéis em Biomedicina, 2004, Londrina.

Moreno, G., A. Bañares and M. Heykoop (1995), Macrolepiota molybdites (Meyer: Fr.) comb. nov., new to the Canary Islands. Mycotaxon 55, 467-471.

Mossebo, D. C., Amougou Akoa and R. Atanga Étémé (2000), Macrolepiota globosa sp. nov. (Agaricaceae) et Nothopanus nsimalenensis sp. nov. (Tricholomataceae): deux nouvelles espèces fongiques (Basidiomycotina) du Cameroun. Mycotaxon 76, 267-278.

Murrill, W. A. (1910), Poisonous mushrooms. Mycologia 2, 255-264.

Natarajan, K. and V. Kaviyarasan (1991), Chlorophyllum molybdites poisoning in India - a case study. Mycologist 5, 70.

Natarajan, K. and B. Manjula (1981), South Indian Agaricales XIV. Indian J. Bot. 4, 50-59.

Pegler, D. N. (1977), A preliminary agaric Flora of East Africa. Kew Bull. Addit. Ser. 6, 1-615.

Pegler, D. N. (1983), Agaric Flora of the Lesser Antilles. Kew Bull. Addit. Ser. 9, 1-668.

Pegler, D. N. (1997), The agarics of São Paulo. An account of the agaricoid fungi (Holobasidiomycetes) of São Paulo State, Brazil. Royal Botanic Gardens, Kew. 68 pp.

Pegler, D. N. and G. D. Piearce (1980), The edible mushrooms of Zambia. Kew Bull. 35, 475-491

Pereira, A. B. (2001), Contribuição ao conhecimento do gênero Lepiota no Brasil II. Pesquisas, Bot. 51, 7-30

Pérez-Silva, E. and T. Herrera (1986), Macromicetos tóxicos: Chlorophyllum molybdites, causante de micetismo gastrointestinal en México. Revista Soc. Mex. Hist. Nat. 38, 27-33

Plant Names Project. International Plant Names Index. Online Database; http://www.ipni.org [permanently updated; accessed in May 2004]

Rammeloo, J. and R. Walleyn (1993), The edible fungi of Africa south of the Sahara. Scripta Bot. Belg. 5, 162

Reid, D. A. and A. Eicker (1991), A comprehensive account of Chlorophyllum molybdites. Bot. Bull. Acad. Sin. 32, 317-334

Rick, J. (1961), Basidiomycetes Eubasidii in Rio Grande do Sul - Brasilia. 5. Agaricaceae. Iheringia, Bot. 8, 301-449
Singer, R. (1948 ['1946']), New and interesting species of Basidomycetes. II. Pap. Michigan Acad. Sci. 32, 103-150

Singer, R. (1951 ['1949']), The Agaricales in modern taxonomy. Lilloa 22, 1-832

Singer, R. (1953a), Four years of mycological work in southern South America. Mycologia 45, 865-891

Singer, R. (1953b), Type studies on Basidiomycetes VI. Lilloa 26, 57-159

Singer, R. (1955), Type studies on Basidiomycetes VIII. Sydowia 9, 367-431

Singer, R. (1969), Mycoflora Australis. Beih. Nova Hedwigia 29, 1-405

Singer, R. (1975), The Agaricales in modern taxonomy, Ed. 3. Verlag J. Cramer, Vaduz. 912 pp.

Singer, R. (1979 ['1978']), Keys for the identification of the species of Agaricales II. Sydowia 31, 193-237

Singer, R. and A. P. L. Digilio (1952 ['1951']), Pródromo de la Flora Agaricina Argentina. Lilloa 25, $5-461$

Soto, M. K., C. C. Carmarán and H. Bruzzi (2000), Suspected poisoning of domestic dogs by Macrolepiota molybdites. Mycologist 14, 50-51

Southcott, R. V. (1974), Notes on some poisonings and other clinical effects following ingestion of Australian fungi. South Austral. Clinics 6, 442-478

Sundberg, W. J. (1971), The genus Chlorophyllum (Lepiotaceae) in California. Madroño 21, 15-20

Vellinga, E. C. (1988), Glossary. In-Flora Agaricina Neerlandica, Vol. 1, ed. C. Bas, Th.W. Kuyper, M.E. Noordeloos and E.C. Vellinga. Balkema, Amsterdam/Brookfield, pp. 54-64

Vellinga, E. C. (1990), Bijzondere waarnemingen en vondsten. Een tropisch paddestoelenparadijs. Coolia 33, 78-79

Vellinga, E. C. (2002), New combinations in Chlorophyllum. Mycotaxon 83, 415-417

Vellinga, E. C. (2003a), Phylogeny and taxonomy of lepiotaceous fungi. Thesis, Ph.D., Universiteit Leiden, Leiden. 259 pp.

Vellinga, E. C. (2003b), Type studies in Agaricaceae Chlorophyllum rachodes and allies. Mycotaxon $\mathbf{8 5}$, 259-270

Vellinga, E. C. and R. P. J. de Kok (2002), Proposal to conserve the name Chlorophyllum Massee against Endoptychum Czern. (Agaricaceae). Taxon 51, 563564

Vellinga, E. C., R. P. J. de Kok and T. D. Bruns (2003), Phylogeny and taxonomy of Macrolepiota (Agaricaceae). Mycologia 95, 442-456

Vellinga, E. C. and M. E. Noordeloos (2001), Glossary. In-Flora Agaricina Neerlandica, Vol. 5, ed. M.E. Noordeloos, Th.W. Kuyper and E.C. Vellinga. A.A. Balkema Publishers, Lisse/Abingdon/Exton/Tokyo, pp. 6-11 
Walleyn, R. and J. Rammeloo (1994), The poisonous and useful fungi of Africa south of the Sahara. Scripta Bot. Belg. 10, 1-56

Watling, R. (1991), A striking addition to the British mycoflora. Mycologist 5, 23

Weresub, K. L. (1971), Congo red for instant distinction between poisonous Lepiota molybdites and edible L. brunnea. Can. J. Bot. 49, 2059-2060

Young, T. (1989), Poisonings by Chlorophyllum molybdites in Australia. Mycologist 3, 11-12

Received: February 28, 2005;

Revised: March 22, 2006;

Accepted: March 14, 2007. 